\title{
Central odontogenic fibroma: a case report with long-term follow-up
}

\author{
Marco T Brazão-Silva', Alexandre V Fernandes ${ }^{3}$, Antônio F Durighetto-Júnior ${ }^{2}$, Sérgio V Cardoso ${ }^{3}$, \\ Adriano M Loyola ${ }^{1,3^{*}}$
}

\begin{abstract}
An osteolytic tumour of the mandible with prominent expansive growth on the alveolar ridge and displacement of the involved teeth is described in a 28-year-old man. The lesion was diagnosed as a central odontogenic fibroma, an uncommon benign neoplasm derived from dental apparatus, and was removed by curettage. The patient remains asymptomatic after thirteen years of follow-up, which supports the claimed indolent behavior of this poorly documented disease and the adequacy of a conservative surgical treatment.
\end{abstract}

\section{Introduction}

Central odontogenic fibroma (COF) is an uncommon benign neoplasm composed by varying amounts of inactive-looking odontogenic epithelium embedded in a neoplastic mature and fibrous stroma [1-12]. The lesion may evolve from a dental germ (dental papilla or follicle) or from the periodontal membrane, and therefore is invariably be related to the coronal or radicular portion of teeth $[2,3]$. Due to its non-exclusive histological features, this lesion may be confused with other entities, such as hyperplastic dental follicles, odontogenic myxomas, and desmoplastic fibromas, which highlight the importance of clinicopathological correlation in the diagnosis of odontogenic fibromas $[2,3,7,12,13]$. Finally, there is little information regarding long term results after surgical treatment of this lesion. We describe a $\mathrm{COF}$ in the right canine/premolar area of the mandible in an adult male. In addition, we discuss relevant issues about the origin, diagnosis and management of the present lesion.

\section{Case report}

A 28-year-old man presented with a painless periodontal swelling in the right side of the mandible. The patient reported five years of evolution, with moderate discomfort during mastication as the only relevant symptom. Oral examination revealed a $2.5 \mathrm{~cm}$ sessile tumour on

\footnotetext{
* Correspondence: loyolaam@yahoo.com.br

${ }^{1}$ General Pathology master degree program, Federal University of Triângulo Mineiro, Uberaba, MG, Brazil

Full list of author information is available at the end of the article
}

the right side of the alveolar ridge of the mandible, between canine and first premolar (Figure 1.A). These teeth were displaced by the lesion without relevant mobility and positive responses were obtained to thermal test of pulp vitality. The lesion had a firm consistency and was covered by a normal overlying mucosa. There were no clinical signs of inflammation in spite of that surface indentations caused by their upper right canine. On radiographs, it was evidenced a rounded unilocular radiolucent alteration surrounded by a thin radiopaque membrane, with some discrete radiopaque spots. There was not radicular resorption albeit the lamina dura of the affected teeth was not apparent in the proximal aspect to the lesion (Figure 1.B). Puncture of the tumor did not revealed liquid content, and a punch biopsy was performed to obtain a fragment with a myxoid appearance.

Microscopically, the sample consisted in a fibrous connective tissue alternated with more vacuolated myxomatous areas. Individual nuclear morphology of the fibroblasts varied from spindle shaped to stellate. Abundant nests and strands of odontogenic epithelium were found, often with a clear or vacuolated cytoplasm, sometimes surrounded by juxtaepithelial hyalinization (Figure 2). Calcification, inflammatory cells and mitotic activity were not observed. Correlation of clinical, radiographic and histopathological features leaded to the diagnosis of central odontogenic fibroma.

The lesion was then entirely removed by curettage under local anesthesia. The microscopic evaluation of this material reveals the same features of the previous 


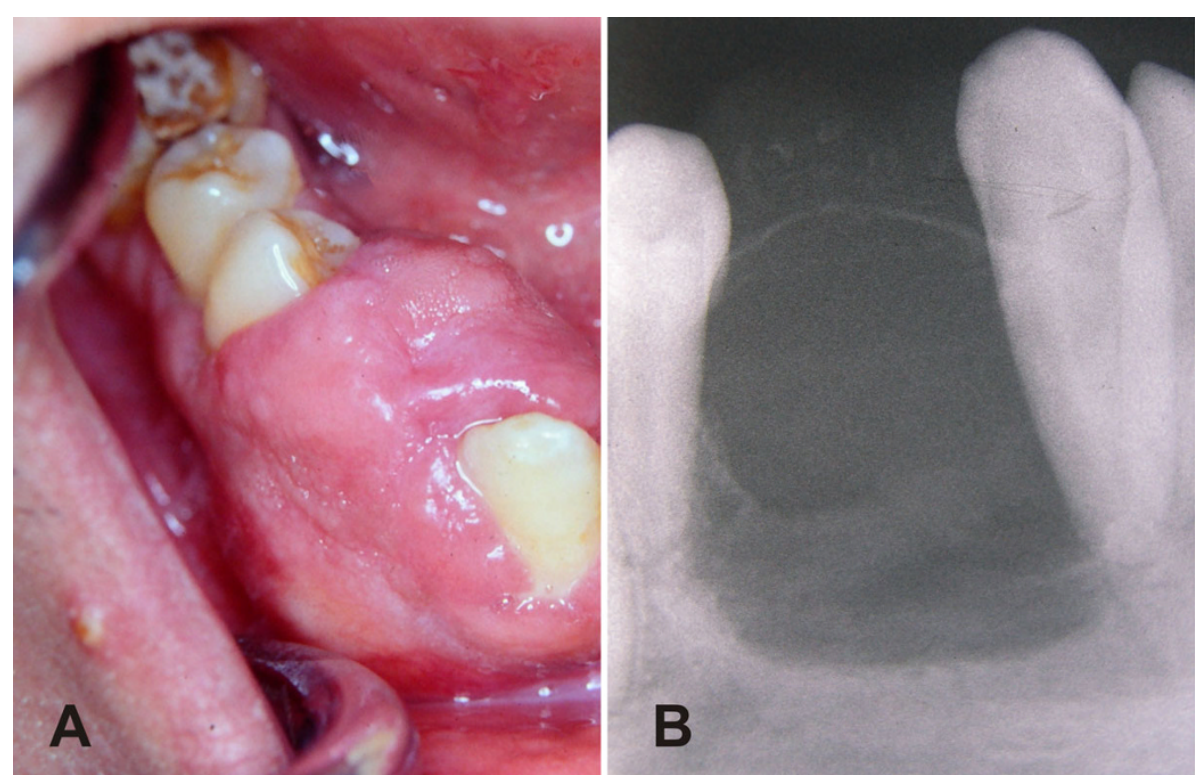

Figure 1 A - Intra-oral view demonstrating gingival swelling in the alveolar ridge between canine and premolar teeth. B - Periapical radiography demonstrating a radiolucent osteolitic lesion with internal osseous septa, and points of calcifications on buccal surface. Besides, shows a thin radiopaque line around the superior aspect of the lesion and resorption of the lamina dura without radicular resorption.

biopsy. All options for rehabilitation were given to the patient, who choice to use a removable partial denture. There was not any relevant event after thirteen years of follow-up.

\section{Discussion}

Up to the present, specific information from approximately 80 patients were reported as single cases or case series in English literature [5,6,8-12,14-17]. It described a female predilection of $2.8: 1$, usually ranging from

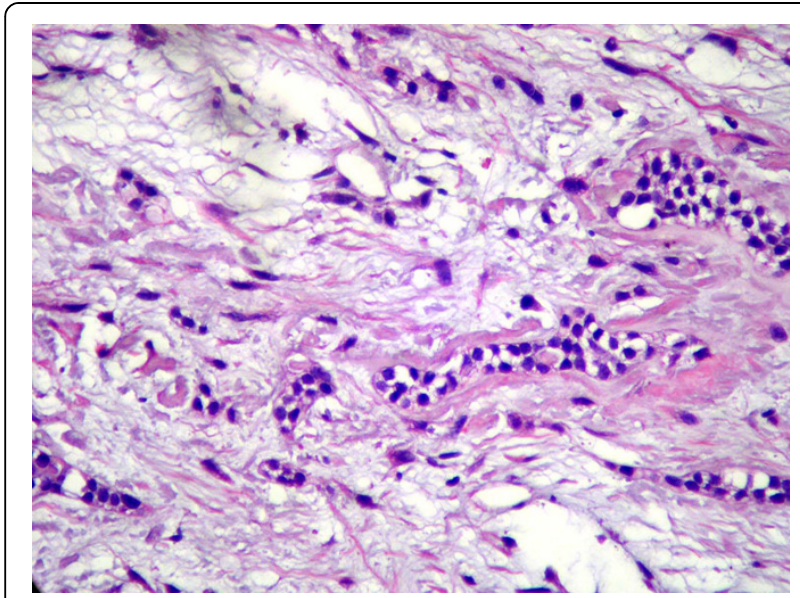

Figure 2 Microscopic view demonstrating a lesion constituted by fibrous connective tissue and abundant nests and strands of inactive-looking OE usually surrounded by basophilic extracellular substance (1000x, hematoxilin-eosin). patients among the second and sixth decade of life. Lesions are similarly found in maxilla and mandible, most of them in the anterior region of the jaws. Tumors are asymptomatic, and claims which exist, are related to their slow growing behavior that displaces and might cause mobility of the adjacent teeth [5-21]. Our patient only claimed the lesion after 5 years, complaining only the discomfort caused by that mass, without mobility or pain.

There are two types of COF. The simple type of COF is composed by a delicate fibrous connective tissue with considerable ground substance yielding a fibromyxoid quality. Seldom rests of small and round odontogenic epithelium, often with vacuolated cytoplasm, may or may not be found [3]. In this sense it might be identical to a hyperplastic dental of an impacted tooth. Since an enlarged but narrow and well-circumscribed radiolucent area should be better regarded as a hyperplastic dental follicle, a lesion depicting persistent, progressive growth, sometimes with calcifications, is compatible with a tumor $[2,3,7]$. Our case was compatible with the socalled odontogenic fibroma complex type (or WHO type). This variant shows abundant islands and strands of apparently inactive odontogenic epithelium and spindle or stellate fibroblasts. Their parenchyma is composed by a connective tissue constituted by interposed bundles of collagen alternating with less cellular and less fibrous regions [1-3]. Irregular calcifications resembling dysplastic cementum, osteoid or dysplastic dentin is also present at variable amounts. 
Table 1 Differential diagnosis: Odondogenic fibroma and similar fibrous lesions of jaws

\begin{tabular}{|c|c|c|c|c|c|}
\hline Features & $\begin{array}{l}\text { Central odontogenic } \\
\text { fibroma }\end{array}$ & Desmoplastic fibroma & Odontogenic myxoma & Ameloblastic fibroma & $\begin{array}{l}\text { Adenomatoid } \\
\text { odontogenic tumor }\end{array}$ \\
\hline Origin & $\begin{array}{l}\text { odontogenic } \\
\text { ectomesenchyme }\end{array}$ & $\begin{array}{l}\text { roblastic/ } \\
\text { jofibroblastic }\end{array}$ & $\begin{array}{l}\text { lontogenic } \\
\text { tomesenchyme }\end{array}$ & $\begin{array}{l}\text { Odontogenic epithelium } \\
\text { and odontogenic } \\
\text { ectomesenchyme }\end{array}$ & Odontogenic epithelium \\
\hline athology & $\begin{array}{l}\text { Interwoven bundles of } \\
\text { collagen embedding } \\
\text { variable amount of } \\
\text { scattered fibroblasts. } \\
\text { Many nests and strands } \\
\text { of inactive-looking OE** } \\
\text { and calcifications can be } \\
\text { found [1-3]. }\end{array}$ & $\begin{array}{l}\text { Interlaced bundles and } \\
\text { whorled aggregates of } \\
\text { densely collagenous } \\
\text { tissue containing uniform } \\
\text { spindled and elongated } \\
\text { fibroblasts/myofibroblasts } \\
\text { [2]. }\end{array}$ & $\begin{array}{l}\text { Stellate and spindle- } \\
\text { shaped cells in a rich } \\
\text { myxoid or mucoid } \\
\text { stroma with few } \\
\text { collagen fibrils. Few OE } \\
\text { islands may be present } \\
{[3,27] \text {. }}\end{array}$ & $\begin{array}{l}\text { Branching and } \\
\text { anastomosing } \\
\text { proliferative OE with } \\
\text { peripheral rim of } \\
\text { columnar cells in a } \\
\text { primitive connective } \\
\text { tissue stroma without } \\
\text { hard tooth formations } \\
\text { [23]. }\end{array}$ & $\begin{array}{l}\text { Variably sized solid } \\
\text { nodules of cuboidal OE } \\
\text { conspicuously with duct- } \\
\text { like structures. } \\
\text { Eosinophilic amorphous } \\
\text { material called "tumor } \\
\text { droplets" can be found } \\
{[28,29] \text {. }}\end{array}$ \\
\hline esentation" ${ }^{\#}$ & $\begin{array}{l}1.5 \% \text { of odontogenic } \\
\text { tumors [4] } \\
\text { Age: } 34.9+19.6[12] \\
\text { M:F }{ }^{*}=1: 2.8[12] \\
\text { Maxilla and mandible in } \\
\text { equal proportions, being } \\
\text { most affected posterior } \\
(73.5 \%) \text { and anterior } \\
(73.5 \%) \text { regions, } \\
\text { respectively }[5,11] .\end{array}$ & $\begin{array}{l}\text { Less than } 1 \% \text { of bone } \\
\text { tumors }[21,30] \\
\text { Age: } 15.1+12[12,30] \\
\text { M:F }=1: 1.2[7,12] \\
15 \% \text { may be painfull [21] } \\
\text { Locally invasive and } \\
\text { aggressive } \\
\text { Almost mandible }(84 \%), \\
\text { and in posterior portion } \\
\text { of both jaws }[21,30]\end{array}$ & $\begin{array}{l}3-20 \% \text { of odontogenic } \\
\text { tumors [4] } \\
\text { Age: } 31.3[31] \\
\text { M:F = 1:2.3 [27] } \\
25 \% \text { may be painful [27] } \\
\text { Locally invasive and } \\
\text { aggressive } \\
\text { Mandible (63\%) at } \\
\text { posterior region and } \\
\text { maxilla at premolar } \\
\text { region [31]. }\end{array}$ & $\begin{array}{l}\text { 1.6\% of odontogenic } \\
\text { tumors [3] } \\
\text { Age: } 9.6[23] \\
\text { M:F }=1.26: 1 \\
\text { Expansive growth } \\
\text { Mandible (80.5\%) } \\
\text { posterior (73.5\%) [23]. }\end{array}$ & $\begin{array}{l}1.7-7 \% \text { of odontogenic } \\
\text { tumors } 9 \text {, OMs } \\
\text { Age:13.2 [28] } \\
\text { M:F = 1:2.6 [28] } \\
\text { The absence of a tooth is } \\
\text { observed } \\
\text { Maxilla (twice mandible) } \\
\text { at anterior region (92.3\%) } \\
{[32]}\end{array}$ \\
\hline Radiology & $\begin{array}{l}\text { Well-defined } \\
\text { radiolucency, unilocular } \\
\text { in smaller (average of } \\
2.2 \mathrm{~cm} \text { ) and multilocular } \\
\text { in larger (average of } \\
4.2 \mathrm{~cm}) \text {. Pinpoint } \\
\text { calcifications may be } \\
\text { present in } 12 \% \text { [3]. }\end{array}$ & $\begin{array}{l}\text { Well-defined, almost } \\
\text { multilocular radiolucency } \\
(76 \%), \text { more likely to } \\
\text { involve bone expansion } \\
\text { and boundary destruction } \\
\text { [21]. }\end{array}$ & $\begin{array}{l}\text { Multilocular (60-80\%) as } \\
\text { "honeycomb", "soap } \\
\text { bubble" or "tennis } \\
\text { racket" aspect with well- } \\
\text { defined borders. Lesions } \\
\text { lower than } 4.0 \mathrm{~cm} \text { may } \\
\text { be unilocular }[22,27,31] \text {. }\end{array}$ & $\begin{array}{l}\text { Well-defined, uni/ } \\
\text { multilocular } \\
\text { radiolucency, in most } \\
\text { cases exhibiting a } \\
\text { radiopaque boundary } \\
{[23,24] \text {. }}\end{array}$ & $\begin{array}{l}\text { unilocular radiolucency } \\
\text { associated with the } \\
\text { crown and often part of } \\
\text { the } \\
\text { root of an unerupted } \\
\text { tooth, with displacement } \\
\text { of neighbouring teeth } \\
\text { [28] }\end{array}$ \\
\hline $\begin{array}{l}\text { Therapy/ } \\
\text { prognosis }\end{array}$ & Curettage/excellent & $\begin{array}{l}\text { Surgical resection/ } \\
\text { tendency of recurrence } \\
{[21]}\end{array}$ & $\begin{array}{l}\text { Surgical resection/ } \\
\text { tendency of recurrence } \\
\text { [22] }\end{array}$ & $\begin{array}{l}\text { Surgical resection/ } \\
\text { tendency of recurrence; } \\
\text { malignant transformation } \\
\text { in } 11.4 \%[23,25] \text {. }\end{array}$ & $\begin{array}{l}\text { Curettage/excellent } \\
{[28,29,32]}\end{array}$ \\
\hline
\end{tabular}

" All tumors generally depicted asymptomatic swellings. ${ }^{*} \mathrm{M}: \mathrm{F}=$ Masculine:Feminine. ${ }^{* *}$ Odontogenic epithelium.

All fibrous lesions of the jaws should be considered to make a safe diagnosis, attempting to both clinical and histopathological aspects, as summarized in table 1. Various papers reported the importance to include the Desmoplastic fibromas (DF) as diagnostic hypothesis against fibrous lesions of the jaw bones $[2,3,12,13,20]$. DF is locally aggressive and invasive, often treated with limb spearing resections. Histologically, DFs are usually far less cellular, with more spindle shaped cells and with intensely collagenous stroma [12]. Besides, the findings such as younger age, ill-defined margins, cortical perforation, pathologic fracture and fast growth would be useful to diagnose DF instead of COF [7,12,20,21].

Similarities between odontogenic myxomas and COF simple type leaded to the disputed hypothesis that the latter entity would merely represent the most collagenous variant of the histological spectrum of the odontogenic myxomas, the so-called myxofibroma [1]. The clinical history of rapid growth with expansive and invasive behavior, associated with the surgical aspect of a sticky or gelatinous tissue, is compatible with myxomas/ myxofibromas. Radiographic aspects might be similar, but the aspect of ameloblastoma (soap bubbles) was expected in larger myxomas [22]. Histologically, the abundance of collagen and greater celullarity favors the diagnosis of COF, but an association with clinicradiographic aspects may be done to exclude the hypothesis of the variant myxofibroma [3].

Ameloblastic fibromas are distinguished from COF by the fact that both the epithelial and mesenchymal components are neoplastic, while in COF, is only the mesenchymal $[3,23]$. It usually affect the canine to molar region, the tumor grows slowly and painlessly, expanding the jaw, similar to the COF presentation. However histologically, the epithelial component is made up of thin branching cords or small nests of odontogenic epithelium with little cytoplasm and basophilic nuclei, often with cubical shape. Larger nests may show a central area of stellate reticulum and there are no hard tooth formations [23,24].

Recurrences are not uncommon to DF (17-72\%), myxoma/myxofibroma (10-33\%), and AF (33\%) [21-23,25]. 
Thus, aggressive surgical approach must be requested for those $[13,22,23]$. The present case represents the largest (thirteen years) postsurgical follow up of COF. There was no relapse, substantiating that conservative surgical procedures is adequate treatments for COF. We found only four cases among the papers that with follow-up greater than nine years, with one relapse $[2,26]$. In spite of central odontogenic fibroma be usually easily removed, not showing any adherence to bone and/or tooth structure, the recurrences were related to insufficient curettage. Herein, because of their benign slow growth characteristic, a clinical identification of recurrence or residual disease could be identified only several years after [26]. Cryotherapy has been used in the maxillofacial region to remove neoplasias such as recurrent myxomas. This therapeutic approach is conservative and has been giving low recurrences ratio [22]. However we proved here that this is not necessary if a diagnosis of COF is well conducted.

\section{Conclusion}

In conclusion, it is essential that oral and maxillofacial surgeons, radiologists and pathologists integrate all relevant and available information to come up with a correct diagnosis and appropriate disease management. We demonstrated that conservative surgery can be performed to treat COF, which consists in a thorough curettage of the lesion. Cytogenetic and biomolecular studies are necessary to explain the true nature and pathogenesis of these diverse similar fibrous lesions, which have so distinct behaviors.

\section{Consent}

Written informed consent was obtained from the patient for publication of this case report and accompanying images. A copy of the written consent is available for review by the Editor-in-Chief of this journal.

\section{Competing interests}

The authors declare that they have no competing interests

\section{Authors' contributions}

All authors read and approved the final manuscript. MT has been involved in drafting the manuscript revising it critically for important intellectual content, and to collect the results from follow-up examinations. SV conceived of the study, and participated in its design and coordination and helped to draft the manuscript. AV and AF have made the final treatment and the clinical follow-up of case, besides substantial contributions to conception and design. AM has given the final diagnosis of case after analysis and interpretation of data.

\section{Acknowledgements}

The authors would like to thank Paulo Rogério de Faria for critically reviewing this paper participating in the sequence alignment. Prof. Loyola and Prof. Cardoso are research fellows of the Brazilian governmental agencies CNPq and FAPEMIG.

\section{Author details}

'General Pathology master degree program, Federal University of Triângulo Mineiro, Uberaba, MG, Brazil. ${ }^{2}$ Oral Diagnosis Section, School of Dentistry, Federal University of Uberlândia, Uberlândia, MG, Brazil. ${ }^{3}$ Oral Pathology
Section, School of Dentistry, Federal University of Uberlândia, Uberlândia, MG, Brazil.

Received: 25 July 2009 Accepted: 13 August 2010

Published: 13 August 2010

\section{References}

1. Philipsen HP, Reichart PA, Sciubba JJ, van der Waal : Odontogenic fibroma. World Health Organization Classification of tumours. Pathology and genetics of Head and neck tumours Lyon: IARC PressBarnes L, Eveson JW, Reichart P, Sidransky D 2005, 315-318.

2. Gardner DG: Central odontogenic fibroma: current concepts. J Oral Pathol Med 1996, 25:556-561.

3. Dunlap CL: Odontogenic fibroma. Semin Diagn Pathol 1999, 16:293-296.

4. Buchner A, Merrell PW, Carpenter WM: Relative frequency of peripheral odontogenic tumors: a study of 45 new cases and comparison with studies from the literature. J Oral Pathol Med 2006, 35:385-391.

5. Ramer M, Buonocore $P$, Krost B: Central odontogenic fibroma-report of a case and review of the literature. Periodontal Clin Investig 2002, 24:27-30.

6. Handlers JP, Abrams AM, Melrose RJ, Danforth R: Central odontogenic fibroma: clinicopathological features of 19 cases and review of the literature. J Oral Maxillofac Surg 1991, 49:46-54.

7. Kaffe I, Buchner A: Radiologic features of central odontogenic fibroma. Oral Surg Oral Med Oral Pathol 1994, 78:811-818.

8. Cercadillo-lbarguren I, Berini-Aytés L, Marco-Molina V, Gay-Escoda C: Locally aggressive central odontogenic fibroma associated to an inflammatory cyst: a clinical, histological and immunohistochemical study. J Oral Pathol Med 2006, 35(Suppl 8):513-516.

9. Cicconetti A, Bartoli A, Tallarico M, Maggiani F, Santaniello S: Central odontogenic fibroma interesting the maxillary sinus. A case report and literature survey. Minerva Stomatol 2006, 55(Suppl 4):229-239.

10. Covani U, Crespi R, Perrini N, Barone A: Central odontogenic fibroma: a case report. Med Oral Patol Oral Cir Bucal 2005, 10(Suppl 2):154-157.

11. Daniels JS: Central odontogenic fibroma of mandible: a case report and review of the literature. Oral Surg Oral Med Oral Pathol Oral Radiol Endod 2004, 98(Suppl 3):295-300.

12. Ikeshima A, Utsunomiya T: Case report of intra-osseus fibroma: a study on odontogenic and desmoplastic fibromas with a review of the literature. Journal of Oral Science 2005, 47(Suppl 3):149-157.

13. Slootweg PJ, Muller MD: Central fibroma of the jaw, odontogenic or desmoplastic. Oral Surg Oral Med Oral Pathol 1983, 56(Suppl 1):61-70.

14. Cercadillo-lbarguren I, Berini-Aytés L, Marco-Molina V, Gay-Escoda C: Locally aggressive central odontogenic fibroma associated to an inflammatory cyst: a clinical, histological and immunohistochemical study. J Oral Pathol Med 2006, 35(Suppl 8):513-516.

15. Cicconetti A, Bartoli A, Tallarico M, Maggiani F, Santaniello S: Central odontogenic fibroma interesting the maxillary sinus. A case report and literature survey. Minerva Stomatol 2006, 55(Suppl 4):229-239.

16. Covani U, Crespi R, Perrini N, Barone A: Central odontogenic fibroma: a case report. Med Oral Patol Oral Cir Bucal 2005, 10(Suppl 2):154-157.

17. Daniels JS: Central odontogenic fibroma of mandible: a case report and review of the literature. Oral Surg Oral Med Oral Pathol Oral Radiol Endod 2004, 98(Suppl 3):295-300.

18. Handlers JP, Abrams AM, Melrose RJ, Danforth R: Central odontogenic fibroma: clinicopathological features of 19 cases and review of the literature. J Oral Maxillofac Surg 1991, 49:46-54.

19. Brannon RB: Central odontogenic fibroma, myxoma (odontogenic myxoma, fibromyxoma), and central odontogenic granular cell tumor. Oral Maxillofac Surg Clin North Am 2004, 16(Suppl 3):359-374.

20. Kaffe I, Buchner A: Radiologic features of central odontogenic fibroma. Oral Surg Oral Med Oral Pathol 1994, 78:811-818.

21. Said-Al-Naief N, Fernandes R, Louis P, Bell W, Siegal GP: Desmoplastic fibroma of the jaw: a case report and review of literature. Oral Surg Oral Med Oral Pathol Oral Radiol Endod 2006, 101:82-94.

22. Rocha AC, Gaujac C, Ceccheti MM, Amato-Filho G, Machado GG: Treatment of recurrent mandibular myxoma by curettage and cryotherapy after thirty years. Clinics (Sao Paulo) 2009, 64(Suppl 2):149-152.

23. Chen Y, Li TJ, Gao Y, Yu SF: Ameloblastic fibroma and related lesions: a clinicopathologic study with reference to their nature and interrelationship. J Oral Pathol Med 2005, 34:588-595. 
24. Nelson BD, Folk GS: Ameloblastic fibroma. Head and Neck pathol 2008, 31:51-53.

25. Lo Muzio, Nocini P, Favia G, Procaccini M, Mignogna MD: Odontogenic myxoma of the jaws: a clinical, radiologic, immunohistochemical, and ultrastructural study. Oral Surg Oral Med Oral Pathol Oral Radiol Endod 1996, 82:426-433.

26. Heimdal A, Isacsson G, Nilsson L: Recurrent central odontogenic fibroma. Oral Surg Oral Med Oral Pathol 1980, 50(Suppl 2):140-145.

27. Martínez-Mata G, Mosqueda-Taylor A, Carlos-Bregni R, de Almeida OP, Contreras-Vidaurre E, Vargas PA, Cano-Valdéz AM, Domínguez-Malagón H: Odontogenic myxoma: clinico-pathological, immunohistochemical and ultrastructural findings of a multicentric series. Oral Oncol 2008, 44:601-607.

28. Handschel JG, Depprich RA, Zimmermann AC, Braunstein S, Kübler NR: Adenomatoid odontogenic tumor of the mandible: review of the literature and report of a rare case. Head Face Med 2005, 24:1-5.

29. Philipsen HP, Reichart PA, Zhang KH, Nikai H, Yu QX: Adenomatoid odontogenic tumor: biologic profile based on 499 cases. J Oral Pathol Med 1991, 20:149-158.

30. Schneider M, Zimmermann AC, Depprich RA, Kübler NR, Engers R, Naujoks CD, Handschel J: Desmoplastic fibroma of the mandible-review of the literature and presentation of a rare case. Head Face Med 2009, 24:1-5.

31. Noffke CE, Raubenheimer EJ, Chabikuli NJ, Bouckaert MM: Odontogenic myxoma: review of the literature and report of 30 cases from South Africa. Oral Surg Oral Med Oral Pathol Oral Radiol Endod 2007, 104:101-109.

32. Awange DO: Adenomatoid odontogenic tumour (adenoameloblastoma)a review. East Afr Med J 1991, 68:155-163.

doi:10.1186/1746-160X-6-20

Cite this article as: Brazão-Silva et al: Central odontogenic fibroma: a case report with long-term follow-up. Head \& Face Medicine 2010 6:20,

\section{Submit your next manuscript to BioMed Central and take full advantage of:}

- Convenient online submission

- Thorough peer review

- No space constraints or color figure charges

- Immediate publication on acceptance

- Inclusion in PubMed, CAS, Scopus and Google Scholar

- Research which is freely available for redistribution

Submit your manuscript at www.biomedcentral.com/submit 